REVIEW

This paper is dedicated to the $70^{\text {th }}$ anniversary of the founding of Physiologia Bohemoslovaca (currently Physiological Research)

\title{
Steroids, Steroid Associated Substances, and Gestational Diabetes Mellitus
}

\author{
Martin HILL ${ }^{1}$, Antonín PAŘÍZEK ${ }^{2}$, Patrik ŠIMJÁK ${ }^{2}$, Michal KOUCKÝ ${ }^{2}$, Kateřina \\ ANDERLOVÁ ${ }^{2}$, Hana KREJČII ${ }^{2}$, Daniela VEJRAŽKOVÁ ${ }^{1}$, Leona ONDŘEJÍKOVÁ ${ }^{1}$, \\ Andrej ČERNÝ ${ }^{2}$, Radmila KANCHEVA ${ }^{1}$
}

${ }^{1}$ Institute of Endocrinology, Prague, Czech Republic, ${ }^{2}$ Department of Obstetrics and Gynecology, General University Hospital and First Faculty of Medicine, Charles University in Prague, Czech Republic

Received August 27, 2021

Accepted November 1, 2021

\section{Summary}

As gestational diabetes mellitus (GDM) is both a frequent and serious complication, steroid levels in pregnancy are extremely elevated and their role in pregnancy is crucial, this review focuses on the role of steroids and related substances in the GDM pathophysiology. Low SHBG levels are associated with insulin resistance and hyperinsulinemia, while also predicting a predisposition to GDM. Other relevant agents are placental hormones such as kisspeptin and $\mathrm{CRH}$, playing also an important role beyond pregnancy, but which are synthesized here in smaller amounts in the hypothalamus. These hormones affect both the course of pregnancy as well as the synthesis of pregnancy steroids and may also be involved in the GDM pathophysiology. Steroids, whose biosynthesis is mainly provided by the fetal adrenal glands, placenta, maternal adrenal glands, and both maternal and fetal livers, are also synthesized in limited amounts directly in the pancreas and may influence the development of GDM. These substances involve the sulfated $\Delta^{5}$ steroids primarily acting via modulating different ion channels and influencing the development of GDM in different directions, mostly diabetogenic progesterone and predominantly anti-diabetic estradiol acting both in genomic and non-genomic way, androgens associated with IR and hyperinsulinemia, neuroactive steroids affecting the pituitary functioning, and cortisol whose production is stimulated by $\mathrm{CRH}$ but which suppresses its pro-inflammatory effects. Due to the complex actions of steroids, studies assessing their predominant effect and studies assessing their predictive values for estimating predisposition to GDM are needed.

\section{Key words}

Gestational diabetes mellitus - Steroidome - Sex hormone binding globulin • Kisspeptin • $\mathrm{CRH}$

\section{Corresponding author}

Martin Hill, Department of Steroids and Proteohormones, Institute of Endocrinology, Národní 8, 116 94, Prague, 116 94, Czech Republic. E-mail: mhill@endo.cz

\section{Introduction}

Gestational diabetes mellitus (GDM) is a serious pregnancy complication, in which women without previously diagnosed diabetes develop persistent hyperglycemia during pregnancy. The women with a normal pre-gravid glucose tolerance but manifestation of GDM in pregnancy have subclinical metabolic dysfunction prior to conception compared with women without GDM (GDM-) (Catalano 2014) and the hyperglycemia during pregnancy is generally induced by glucose intolerance due to dysfunction of pancreatic $\beta$-cells and in the context with chronic insulin resistance (IR) (Buchanan and Xiang 2005, Xiang et al. 2013). Advanced maternal age, obesity and a family history of diabetes are common risk factors of GDM. GDM is regularly associated with macrosomia, birth complications in the infant, increased risk of maternal cardiovascular disease and predisposition to type 2 
diabetes mellitus (DM2) in both mother and child (Plows et al. 2018). The prevalence of GDM is about $15 \%-20 \%$ of pregnancies worldwide with an increasing trend linked to the accelerating obesity (Mirghani Dirar and Doupis 2017, Plows et al. 2018, Wang et al. 2019). A number of interrelated factors affecting both insulin secretion and resistance are involved in GDM pathophysiology (Vejrazkova et al. 2014). Several genetic variants significantly associated with genes related to insulin secretion and insulin receptors were reported in women with GDM (GDM+) (Mirghani Dirar and Doupis 2017). Human pregnancy is also associated with pronounced changes in the levels of a number of bioactive substances including steroids (Vejrazkova et al. 2014).

\section{GDM and blood glucose homeostasis}

In a fasting state, low glucose levels keep insulin levels low as well, while the levels of the counterregulatory hormones glucagon, adrenaline and corticosteroids are elevated. Conversely, in a state of satiety, insulin is released from pancreatic $\beta$-cells, reducing glucose levels through its uptake in muscle cells and adipocytes as well as by preventing glycogenolysis and gluconeogenesis in the liver (Ropero et al. 2008).

While the normal pregnancy is accompanied by lower insulin sensitivity (IS) reduced hepatic insulin extraction, lower glucose effectiveness, higher levels of leptin at lower concentrations of adiponectin, increased lipolysis and higher levels of triglycerides in white adipose tissue (WAT) and by increased WAT expansion, the pregnancy complicated with GDM is additionally associated with increased levels of inflammatory cytokines, higher macrophage infiltration, and pronouncedly increased lipolysis at prominently lower IS. In contrast to healthy pregnancy with mild IR, the pregnancy complicated with GDM exhibit severe IR, hyperglycemia, leptin resistance, hyperlipidemia, release of inflammatory cytokines, and oxidative stress. GDM+ women are unable to compensate for the IR of pregnancy by intensified insulin secretion. However, the mechanisms of $\beta$-cell adaptation are not fully understood. (Kautzky-Willer et al. 1997, Moyce and Dolinsky 2018).

Early in gestation, insulin secretion increases, stimulating the glucose uptake into adipose tissue to satisfy the rising energy demands in later pregnancy. However, various placental hormones like female sex steroids, cortisol, leptin, placental lactogen, and placental growth hormone induce an IR. This results in slightly elevated blood glucose, which is swiftly transported across the placenta to fulfill the growing energy needs of the fetus. Furthermore, there is also breakdown of fat stores inducing a further increase in blood glucose as the levels of free fatty acids. The mother recompenses these needs on the account of pancreatic $\beta$-cells hypertrophy and augmented GSIS (Plows et al. 2018).

In late gestation the maternal system switches to the catabolic phase and IR (associated with stimulated lipolysis, raised free fatty acid (FFA) levels, and hyperlipidemia) is natural but transient. In spite of this transformation, maternal blood glucose remains constant or even slightly declines with advancing gestation primarily due to increased pancreatic secretion of maternal insulin. Even though the peripheral tissues are more insulin resistant in pregnancy at continuing production of hepatic glucose, glucose homeostasis in a healthy pregnancy is reached via increasing insulin secretion to overcome the IR (Moyce and Dolinsky 2018). However, in mothers with GDM, $\beta$-cells may become damaged due to overproduction of insulin, which permanently exhausts the cells. Furthermore, GDM is also associated with upregulated gluconeogenesis in the liver (Plows et al. 2018). While in normal pregnancy the maternal IS returns to pre-pregnancy levels shortly after labor, in GDM+ women, problems frequently persist in the postpartum period and may sooner or later develop to overt DM2 (Buchanan and Xiang 2005, Plows et al. 2018, Vejrazkova et al. 2014). To maintain euglycemia in the mother, normal pregnancy is accompanied by about $50 \%$ decrease in insulin-mediated glucose disposal and approximately doubled insulin secretion. (Vejrazkova et al. 2014).

The $\beta$-cell death is reduced in GDM+ women but this phenomenon is linked to compromised insulin production and hyperglycemia and does not contribute to the development GDM. The $\beta$-cell dysfunction in GDM+ women is independent of obesity but correlates with the severity of glucose intolerance. While the insulin secretion is insufficient or unaffected in lean GDM+ women (Kautzky-Willer et al. 1997), obese GDM+ women exhibit raised increase in insulin response at suppressed IS and hepatic glucose production during insulin infusion with advancing gestation when compared with a matched control group (Catalano et al. 1999). The weakening of $\beta$-cell function is most apparent in late pregnancy due to growing inability of the endocrine pancreas to satiate the raising metabolic demand (Kenna et al. 2016, Saisho et al. 2010, Xiang et al. 2013).

Without a substantial growth of insulin secretion and independently of baseline age, obesity, diet, physical activity, changes in body weight and additional 
pregnancies, GDM+ women exhibit a faster decrease in both $\beta$-cell compensation and IS during the 4-year follow-up postpartum when compared with their GDM- counterparts. The more pronounced weakening of the $\beta$-cell compensation in GDM+ patients is substantially but not entirely explained (about $50 \%$ ) by differences between GDM+ and GDM- groups. Other factors like genetic predisposition to GDM that may contribute to additional explanation of this phenomenon (Kwak et al. 2012, Xiang et al. 2013). In general, each degree of the glucose intolerance in pregnancy including GDM is a strong predictor for the development of DM2 in future (Kramer et al. 2014).

\section{Sex hormone binding globulin}

Sex hormone-binding globulin (SHBG) is produced by the liver and its half-life is one week. Insulin is an important regulator of $\mathrm{SHBG}$, inhibiting its production in hepatocytes. Besides the liver, SHGB can also be synthesized by placental trophoblastic cells during pregnancy. SHBG is a glycoprotein that inactivates unconjugated sex steroids and serves as a transporter and reservoir for future use. In addition to insulin, SHBG synthesis is also inhibited by testosterone and prolactin and stimulated by estradiol. (Kopp et al. 2001, Zhang et al. 2018).

In pregnancy, defective insulin signal transduction receptors and glucose transport proteins were found in the placental tissue of GDM patients. SHBG is involved in the regulation of insulin signaling. Therefore, a decrease in expression may result in a simultaneous decrease in expression of relevant insulinsignaling components in placental tissue and subsequent insulin resistance (Zhang et al. 2016).

$\mathrm{Up}$ to the third trimester, SHBG levels are reduced in GDM+ patients compared to controls. Low SHBG levels are associated with increased IR and hyperinsulinemia and appear to be the best predictor of GDM. However, the SHBG concentrations are not associated with peripheral IS (see also review (Bartha et al. 2000, Vejrazkova et al. 2014). Although some authors did not find an association between SHBG and GDM (McElduff et al. 2006), most of them demonstrate that low circulating levels of SHBG strongly predict the risk of DM2 (Ding et al. 2009, Tawfeek et al. 2017) and are also low in GDM+ patients (Faal et al. 2019). Moreover, low pre-pregnancy SHBG levels are also tightly associated with a predisposition to GDM (Hedderson et al. 2014).

\section{Peptide hormones regulating steroid production}

\section{Kisspeptin}

Kisspeptins primarily originating in the hippocampal dentate gyrus form a neuropeptide family playing a key role in the initiation of puberty and in female fertility, when kisspeptin ensures pulsatile $\mathrm{GnRH}$ release and subsequent secretion of gonadotropins. However, the main source of kisspeptin during pregnancy is the placenta. Kisspeptins, encoded by KISS1 gene (and particularly the main product kisspeptin-54 protein also known as metastin) are potential biomarkers of a number of pregnancy complications and processes including miscarriage, preeclampsia, gestational trophoblastic neoplasia (GTN), fetal development (where kisspeptin provides the brain sex differentiation), and parturition (where kisspeptin stimulates oxytocin secretion). Kisspeptin levels considerably raise during pregnancy (900-fold surge in the first trimester and about 7,000-fold escalation in the third trimester in comparison with non-pregnant women). Interestingly, during pregnancy, kisspeptin mRNA levels do not reflect its serum concentration, with mRNA expression even having a paradoxically descending trend (Hu et al. 2019). Kiss1R are expressed in internal, fetal zone of the fetal adrenal (FZFA) from week 8 of gestation until delivery, with kisspeptin levels positively correlated with the growth of fetal adrenal (FA) volume in the second trimester (Katugampola et al. 2017).

Kisspeptin and its receptor, Kiss1R, are expressed in the central nervous system, pancreas, adipose tissue, testes, and spleen. A strong expression of Kiss1R mRNA was found in the tissue of the FA and expression of Kiss1R protein was located in FA definitive zone and in the transition zone from week 14 to week 36 of gestation. The increase in Kiss1R expression in mid-gestation between weeks 13 and 22 of gestation is in parallel with the increase in SULT2A1 (converting DHEA to DHEAS) mRNA expression, suggesting that FZFA is the target tissue for kisspeptin, especially in the second trimester. High circulating levels of kisspeptin in the FA suppress Kiss1R expression most probably to ensure optimal regulation of steroid production (Katugampola et al. 2017).

ACTH secerned from the fetal pituitary gland is one of the key growth regulators of the FA, however placental CRH and estrogens also play important roles in the FA development. The rapid FA growth and FZFA steroid production during the second trimester are not 
accompanied by the ACTH increase. Instead, the CRH levels in human climax near parturition (week 35 of gestation). This indicates that in addition to ACTH, other factors specific to pregnancy also regulate FZFA growth and activity in the second trimester of pregnancy (Katugampola et al. 2017).

Kisspeptin stimulates DHEA production in FZFA between week 10 and week 22 of gestation with its effect comparable to that of $\mathrm{ACTH}$ or $\mathrm{CRH}$. While the combination of kisspeptin with ACTH has a stimulating effect on DHEAS production in FZFA, its combination with CRH does the opposite. Consequently, it turns out that the resulting FZFA activity is contingent on a combination of factors involving $\mathrm{ACTH}$, kisspeptin, $\mathrm{CRH}$, and estrogens, which are mostly of placental origin (outside ACTH). Like $\mathrm{CRH}$ levels, estrogen levels progressively increase with gestational age (Katugampola et al. 2017).

Kisspeptin increases (via its receptor GPR54) GSIS in $\beta$-cells of pregnant women. Therefore, low kisspeptin levels are associated with the risk of GDM. Kisspeptin thus provides the placental signal needed to adapt $\beta$ cells during pregnancy for maintaining glucose homeostasis (Bowe et al. 2019, Simpson et al. 2018). The relationship between kisspeptin and insulin secretion is independent of other key determinants of glucose homeostasis, such as IS, glucose stress test results, adiposity, age and gender (Andreozzi et al. 2017).

\section{CRH}

Outside of pregnancy, corticoliberin (CRH) is the hypothalamic hormone controlling, through stimulation of ACTH secretion in the pituitary gland, cortisol production in the adult adrenal gland. The hypothalamic-pituitary-adrenal (HPA) axis in non-pregnant subjects is based on a negative feedback loop between the final active hormone cortisol, ACTH and CRH. In pregnancy, after the luteo-placental shift, $\mathrm{CRH}$ is primarily expressed in the human placenta, creating a positive feedback loop between cortisol and $\mathrm{CRH}$, while ACTH production stagnates. $\mathrm{CRH}$ directly stimulates the production of $\Delta^{5}$ steroid sulfates in the fetal zone of the fetal adrenal (FZFA) and cortisol synthesis in the fetal adrenal transition zone. As for CRH's key physiological role in pregnancy, some authors hypothesize the so-called "placental clock" (Hill et al. 2010a). This most sophisticated hypothesis to date on the role of placental CRH in pregnancy in all probability explains how this proteohormon determines the duration of pregnancy and the start of labor (McLean et al. 1995,
Sandman et al. 2006, Smith and Nicholson 2007). A number of experimental data support this concept, yet some important questions remain unanswered (Gangestad et al. 2012). Almost all placental CRH ( $>99 \%$ ) passes into the maternal circulation and only less than $1 \%$ of placental CRH passes into the fetus (Campbell et al. 1987). CRH levels in the maternal circulation in the 3rd trimester of pregnancy exceed CRH levels in early pregnancy by approximately 3 orders of magnitude and are more than an order of magnitude higher than $\mathrm{CRH}$ levels in the fetus (Gangestad et al. 2012, Goland et al. 1994, Goland et al. 1988, Sasaki et al. 1987). Therefore, $\mathrm{CRH}$ levels in the maternal circulation are almost exclusively of placental origin (Gangestad et al. 2012, Smith et al. 2001).

Some authors have raised the question of why the placenta secretes the vast majority of CRH into the maternal bloodstream and proposed a different concept explaining CRH's function (Gangestad et al. 2012). However, these authors did not completely reject the concept based on the "placental clock". Unlike previous studies that considered cortisol to be harmful to the fetus, they suggest that cortisol, on the other hand, is beneficial to the fetus because it stimulates glucose levels via liver gluconeogenesis and maintains insulin insensitivity leading to a reduction in peripheral glucose consumption, thereby providing a greater flow of glucose through the placenta to the fetus (Gangestad et al. 2012). Gangestad et al. suggested that cortisol works in the same way as placental hormones (human placental lactogen (hPL) and human growth hormone to ensure glucose uptake in the placenta and subsequent glucose transport to the fetus (Gangestad et al. 2012). Furthermore, Smith et al. (Smith et al. 2001) reported that peripheral administration of $\mathrm{CRH}$ increases fat oxidation. While human growth hormone and hPL have direct effects, placental CRH acts by stimulating maternal cortisol production and placental CRH production increases in response to increasing fetal energy needs. For example, starvation increases CRH production and shortens pregnancy duration (Herrmann et al. 2001). For this reason, CRH production is also higher in multiple pregnancies to meet greater demands for maternal energy supply (Gangestad et al. 2012). Placental CRH also mediates insulin secretion (Schmid et al. 2011) and proliferation of pancreatic $\beta$-cells (Mack and Tomich 2017). On the other hand, overly high CRH levels in pregnant women may induce a pathological grade IR and hyperglycemia leading to GDM (Wolfe et al. 1988). 


\section{Steroids, steroidogenic enzymes, and steroid- related receptors}

Local islet steroidogenesis and pancreatic steroid receptors

There are a number of results documenting the ability of mammalian pancreas to synthesize steroids (Mauvais-Jarvis 2016). This organ expresses steroidogenic enzymes such as cholesterol desmolase (CYP11A1), responsible for the first, limiting step in steroidogenesis, type 3 17 $\beta$-hydroxysteroid dehydrogenase (HSD17B3) converting inactive androstenedione to active testosterone, type 1 17ß-hydroxysteroid dehydrogenase (HSD17B1) transforming inactive estrone to active estradiol, and type 12 17 $\beta$-hydroxysteroid dehydrogenase (HSD17B12), which is specifically pancreatic and works in the opposite direction to HSD17B1. The steroid C17-hydoxylase, C17,20 lyase (CYP17A1) is active in the $\beta$ cells in both hydroxylase and lyase steps and is co-localized with CYP11A1. Furthermore, the CYP11A1 is also colocalized with $3 \beta$-hydroxysteroid dehydrogenase- $\Delta^{4 / 5}$ isomerase HSD3B and the $\beta$-cells also express aromatase (CYP19A1) and 5 $\alpha$-reductase (SRD5A). Therefore, the pancreatic tissue is capable to synthesize several active steroid hormones such as progesterone, testosterone, $5 \alpha$-dihydrotestosterone, estradiol, and neuroactive steroids, whose concentrations in the pancreatic tissue roughly exceed their blood concentrations by an order of magnitude. The steroids above may then act on estrogen and androgen receptors in intracrine and paracrine ways and may be inactivated in the same way. (Mauvais-Jarvis 2016, Morales et al. 1999, Robles-Diaz and Duarte-Rojo 2001). Progesterone receptors are expressed in the pancreas, predominantly in cells that produce glucagon. In addition, pancreatic tissue also expresses androgen receptors (Robles-Diaz and Duarte-Rojo 2001).

Of the steroids synthesized in the pancreas, estradiol, progesterone, and androgens are involved in stimulating insulin secretion. At physiological concentrations, estradiol increases insulin secretion in the presence of glucose by acting on the membrane receptor that closes the ion $\mathrm{K}_{\mathrm{ATP}}$ channels. In addition, treatment with estradiol successfully prevents the development of DM2. In mice, treatment with progesterone leads to higher insulin production. In rats, the $5 \alpha$-reduced metabolites of C19 steroids (epiandrosterone and $5 \alpha$-dihydrotestosterone) reduce the harmful effects of interleukin $1 \mathrm{~b}$ and NO-mediated damage on insulin secretion (Robles-Diaz and Duarte-Rojo 2001).
$\Delta^{5}$ Steroids

The main source of $\Delta^{5}$ steroids outside pregnancy is primarily the adrenal cortex. Whereas C21 $\Delta^{5}$ steroids (pregnenolone, 17-hydroxypregnenolone) are synthesized in zona fasciculata similarly to cortisol, the source of C19 $\Delta^{5}$ steroids (DHEA, androstendiol) is primarily zona reticularis. In men, a smaller proportion of C19 $\Delta^{5}$ steroids may also arise as intermediates for testosterone synthesis. In both sexes, however, both $\mathrm{C} 21$ and C19 $\Delta^{5}$ steroids are produced in the human adrenal gland primarily in the form of relatively hydrophilic and well soluble sulfates and consequently also circulate in blood in concentrations 1-3 orders of magnitude higher than their free analogues (Hill et al. 1999, Mitamura et al. 2003, Sulcova et al. 1997, Tagawa et al. 2004). The ratio of $\mathrm{C} 19$ to $\mathrm{C} 21 \Delta^{5}$ adrenal steroids grow with growing cytochrome B5 (CYB5) activity in adrenal cortex (Rege et al. 2016).

In contrast to non-pregnant subjects, the main source of pregnancy steroids is the fetal adrenal cortex primarily producing the sulfates of $\Delta^{5}$ steroids (pregnenolone, 17-hydroxypregnenolone, DHEA, androstenediol). These steroids circulate in the fetal blood in concentrations mostly exceeding 1-3 orders of magnitude their values outside pregnancy. Only the levels of DHEA sulfate are lower in pregnancy than outside pregnancy. The sulfates of the $\Delta^{5}$ steroids are then easily transported to the placenta, even at excessive concentrations, where they are first swiftly desulfated by steroid sulfatase (STS) and then readily converted by type $13 \beta$-hydroxysteroid dehydrogenase (HSD3B1) to the corresponding $\Delta^{4} \quad$ steroids (progesterone, 17-hydroxyprogesterone, androstenedione, testosterone) as activities of the aforementioned enzymes in placenta are extremely high. Alternatively, since the placenta has only very low activity of CYP17A1, there is no significant placental conversion of 17-hydroxy-C21 steroids to their C19 analogues as well as conversion of 17-deoxy-C21 steroids to their 17-hydroxy- analogues. The $\Delta^{4}$ steroids (mainly androstenedione) resulting from the released C19 $\Delta^{5}$ steroids (DHEA, androstenediol) are then suitable substrates for the biosynthesis of estradiol, as the placental activity of CYP19A1 that catalyzes this step is also very high (2015, Hill et al. 2010a).

While the origin of fetal $\Delta^{5}$ steroids is detailed above, in the maternal compartment, the major sources of C19 $\Delta^{5}$ steroids androgens are zona reticularis in the maternal adrenal cortex and also the maternal ovaries. A baboon study showed an inhibitory effect of estradiol on the production of DHEA/DHEAS in zona reticularis in pregnant women, consistent with the observed 
decrease in DHEAS production in maternal blood. Even with placenta maintenance, fetal removal (fetectomy) caused a decrease in estradiol levels in the maternal circulation, while increasing levels of DHEA/DHEAS. In addition, estradiol substitution by addition to the maternal circulation inhibits the decrease in maternal DHEA/DHEAS levels at unchanged DHEA/DHEAS metabolic clearance rates. This confirms that the sources of maternal estradiol are sulfated C19 steroids synthesized in the FZFA and transformed by placenta into estradiol, which then enters the maternal circulation (Hill et al. 2010a, Makieva et al. 2014). At the same time, it shows that the decrease in $\mathrm{C} 19$ steroids in the maternal zona reticularis depends primarily on the production of $\mathrm{C} 19$ steroids in FZFA (Makieva et al. 2014).

Although the $\Delta^{5}$ do not operate in a genomic way they are effective as modulators of ionotropic receptors (especially sulfates) and affect numerous physiological functions particularly in human immune system (Sterzl et al. 2003, Sterzl et al. 1999, Tagawa et al. 2004, Tagawa et al. 2002, Tagawa et al. 2001, Tagawa et al. 2000).

Steroid levels in pregnant women and fetuses often range in excess of 1-3 orders of magnitude of these concentrations outside pregnancy (Hill et al. 2011, Hill et al. 2014). Simultaneously, steroids affect both IS in tissues and insulin secretion in pancreatic $\beta$-cells (Vejrazkova et al. 2014), especially at excessive concentrations that are common during pregnancy (Hill et al. 2011, Hill et al. 2014). For example, pregnenolone sulfate (PregS) stimulates insulin secretion by positively modulating non-selective type 3 melastatin ion channels (TRPM3), where this steroid conjugate opens these ion channels for $\mathrm{Ca}^{2+}$ penetration even at concentrations common outside pregnancy (Naylor et al. 2010). At the same time, PregS levels during pregnancy in the mother and fetus are in excess of those outside pregnancy by 1 and 2 orders of magnitude, respectively (Hill et al. 2011, Hill et al. 2014). Dehydroepiandrosterone sulfate (DHEAS) also has a similar effect on TRPM3 like PregS (Majeed et al. 2010) but DHEAS levels in pregnancy are either comparable or rather lower than outside pregnancy. Activation of TRPM3 channels by the aforementioned steroids leads to the activation of rapidly accelerated fibrosarcoma (RAF) kinases and extracellular signalregulated kinases (ERK) and subsequently insulin secretion. PregS also activates signal cascades involving the amplified expression of activator protein 1 (AP-1) and transcription factors Egr-1, c-Jun, and c-Fos in the pancreatic $\beta$-cells. Voltage gated L-type $\mathrm{Ca}^{2+}$ channels are also involved in $\beta$-cell activation, but their expression is insufficient to activate the transcription factors mentioned above (Lesch et al. 2014). In addition to TRPM3 modulation, PregS may also be involved in insulin secretion through positive modulation type 1 melastatin ion channels (TRPM1) (Lambert et al. 2011). Furthermore, PregS and another also abundant steroid conjugate isopregnanolone sulfate (progesterone metabolite) (reaching micromolar concentrations during pregnancy) inhibit specific proton-activated outwardly rectifying anion channels (PAORAC). This may further contribute to increased $\beta$-cell activity (Drews et al. 2014).

Moreover, PregS (at concentrations common in fetal circulation) inhibits nicotine-acetylcholine receptors (nAChR) and inhibits the influx of $\mathrm{Ca}^{2+}$ and $\mathrm{Na}^{+}$ions into $\beta$-cells, thereby suppressing insulin secretion (Kudo et al. 2002). DHEAS, independent of pregnancy, has a similar effect (Paradiso et al. 2000). The nAChR containing $\alpha_{7}$ and $\beta_{2}$ subunits are thus involved in maintaining energy homeostasis and IS (Somm et al. 2014). The data above indicates that in addition to stimulating insulin secretion, the sulfated $\Delta^{5}$ steroids may also reduce insulin secretion and peripheral IS but a question remains which direction prevails regarding the resulting influence on GDM.

Like the effects of PregS, the effects of C19 $\Delta^{5}$ steroids are not clear-cut in relation to the pathophysiology of DM2 (and GDM). On one hand, already a single dose of DHEA induces alterations in insulin receptor, IRS-1, IRS-2, and Act-1 protein levels while increasing the weight of pancreatic $\beta$-cell mass and GSIS (Medina et al. 2006, Morimoto et al. 2011). Another study reports increased GSIS in DHEAS-treated rat insulinoma RINm5F-cells (Liu et al. 2006a). Like some of its reduced metabolites, DHEA mitigates the cytotoxic effect of interleukin $1 \mathrm{~b}$ and its harmful effect on glucose transport (Liu et al. 2006a). DHEA supplementation in female rats after ovariectomy also improves GSIS disrupted by a high-fat diet (Veras et al. 2014). Several animal studies during feeding indicate that DHEA/DHEAS reduce glycaemia, suggesting that intestinal factors are likely to contribute to these results (Liu et al. 2006a).

On the other hand, three-day cultivation with BRIN-BD11 rat pancreatic cells with either DHEAS $(30 \mu \mathrm{M})$ or DEX $(100 \mathrm{nM})$ diminishes the total number of cells, reduces cell viability, reduces insulin content, and impairs insulin secretion and responsiveness in these cells. The DHEAS application reduces insulin secretion in BRIN-BD11 cells by roughly one half, with slightly less pronounced reductions in high glucose levels (16.7 mM) compared to low $(1.1 \mathrm{mM})$ or mean glucose levels $(5.6 \mathrm{mM})$. Insulin response remains unchanged 
after DHEAS administration at low glucose concentrations, decreases by about a fifth at moderate concentrations, and remains almost unchanged again at high glucose concentrations. Insulin secretion decreases substantially after DHEAS administration both in the presence of various secretagogues $(\mathrm{KCl} 30 \mathrm{nM}$, alanine $20 \mathrm{mM}, \mathrm{Ca}^{2+} 7.68 \mathrm{nM}$ forskolin $25 \mu \mathrm{M}$, PMA $10 \mathrm{nM}$ ) as well as without them (Liu et al. 2006b). In rat INS-1 cells, DHEA (through a rapid non-genomic mechanism) weakens $\mathrm{Ca}^{2+}$ release and inhibits insulin secretion stimulated by the insulin agonist carbachol. These results support the existence of a specific plasma membrane receptor for DHEA that mediates this signal transduction pathway by G-proteins (Morimoto et al. 2011).

\section{Progesterone}

The origin of progesterone depends largely on gender and, in women, on menstrual cycle and pregnancy. While low levels of circulating progesterone are more likely to be of adrenal origin in males and females in the follicular phase of the cycle, women in the luteal phase are clearly dominated by progesterone of ovarian origin, and after the luteo-placental shift of pregnancy, progesterone is almost exclusively of placental origin in both mother and fetus (Kancheva et al. 2007). Two routes are involved in the synthesis of pregnancy progesterone, although biosynthesis of pregnancy progesterone takes place in placenta in both cases. The first route depends on the transport of maternal LDL cholesterol into the placenta and its subsequent conversion to pregnenolone, which is catalyzed by the enzyme cholesterol desmolase (CYP11A1) and then on the conversion of pregnenolone to progesterone catalyzed by HSD3B1. The second route of progesterone formation depends on the delivery of significant amounts of pregnenolone sulfate from the adrenal gland of the fetus (circulating in micromolar concentrations in the fetus), its subsequent hydrolysis catalyzed by placental STS, and further conversion of the released pregnenolone, which is identical to the first route of progesterone formation. Because during transplacental steroid passage towards the fetus, oxidative conversions towards oxo-groups in positions $\mathrm{C} 3, \mathrm{C} 17$ and $\mathrm{C} 20$, are generally preferred, levels of progesterone (20-oxo steroid) in fetal blood are at micromolar concentrations, whereas in maternal blood progesterone circulates only in concentrations of hundreds of nanomoles. Conversely, the proportion of $20 \alpha$-dihydroprogesterone ( $20 \alpha$-hydroxy steroid) is higher in the mother compared to the fetus (Hill et al. 2010a, Hill et al. 2010b, Hill et al. 2011).

The primary role of progesterone lays in female reproductive functioning during the menstrual cycle and in pregnancy. Progesterone is important as a pregnancy stabilizing steroid and also significantly affects glucose homeostasis in pregnancy. Progesterone (whose receptors are present in $\beta$-cells) is primarily a diabetogenic steroid that acts by suppressing the expression of type 4 glucose transporter (GLUT-4). Increased endocrine pancreatic activity in the $3^{\text {rd }}$ trimester of pregnancy is related to increased progesterone levels and is an adaptive response to the increasing energy needs of a fetus requiring increased glucose and lipid intake. Progesterone works in combination with other hormones such as hPL, estradiol or cortisol (Bernard-Kargar and Ktorza 2001, Morimoto et al. 2011, Wilcox 2005). Progesterone is likely to be the central regulator of $\beta$-cell proliferation in response to metabolic challenges such as IR (Branisteanu and Mathieu 2003, Mauvais-Jarvis 2016). For example, the therapeutic use of its metabolite 17-hydroxyprogesterone increases the risk of GDM (Rebarber et al. 2007). Furthermore, progesterone antagonists suppress glucose levels. Pancreatic islets from progesterone $\mathrm{KO}$ mice were reported to be larger and produce more insulin due to $\beta$-cell proliferation and $\beta$-cell weight gain. (Picard et al. 2002).

Progesterone, unlike sulfated $\Delta^{5}$ steroids, inhibits the permeability of TRPM3 channels already at levels common in the luteal phase of the menstrual cycle (Majeed et al. 2012). At the same time, the progesterone levels in maternal and fetal circulation are still 1 to 2 orders of magnitude higher (Hill et al. 2011, Hill et al. 2014). Animal experiments indicate that nuclear progesterone receptors may also be involved in GDM pathophysiology (Picard et al. 2002). Unlike inhibition of action in TRPM3 channels, progesterone (at concentrations common in the luteal phase) and also DHEA (at physiological concentrations) activate purinergic ionotropic P2X receptors (De Roo et al. 2010, De Roo et al. 2003). At the same time, subtypes of P2X receptors are expressed in different tissues, including $\beta$-cells, and their activation facilitates (at low glucose concentrations) the influx of $\mathrm{Ca}^{2+}$ and $\mathrm{Na}^{+}$ions, with subsequent depolarization of the cell membrane and secretion of insulin (Burnstock 2014).

Administration of progesterone and estradiol to female rats results in an increase in GSIS while increasing glucose tolerance (Mauvais-Jarvis 2016, Nielsen 1984). In MIN6 cells (mouse insulinoma cells) and RIN 1046-38 cells (rat insulinoma cells), progesterone increases glucokinase activity (GK). Thus, an increase in both basal and glucose-stimulated insulin secretion during pregnancy may be related to high levels 
of progesterone. However, these effects may limit the ability of lactogenic hormones to increase GSIS in late gestation (Morimoto et al. 2011).

However, the effects of progestogens on GSIS are contradictory as progesterone rapidly and specifically inhibits GSIS $\left(\mathrm{IC}_{50}=10 \mu \mathrm{M}\right.$ at $8.4 \mathrm{mM}$ glucose) in rat $\beta$-cells. On the outer surface of the $\beta$-cell plasma membrane, progesterone reduces the inlet of $\mathrm{Ca}^{2+}$ ions into the cell through the blockade of L-type voltagegated $\mathrm{Ca}^{2+}$ channels (but does not inhibit insulin secretion stimulation in the absence of $\mathrm{Ca}^{2+}$ ) (Straub et al. 2001). Several authors report that unlike prolactin and placental lactogen, which stimulate insulin secretion, progesterone suppresses their effects by down-regulation of $\beta$-cell function in the later stages of gestation (Kawai and Kishi 1999, Morimoto et al. 2011, Shao et al. 2004, Weinhaus et al. 2000).

\section{Testosterone}

Besides massive testosterone synthesis in adult male testicles, this active androgen can also be synthesized in both sexes in the adrenal zona reticularis, which in addition to weak or inactive androgens such as DHEA, DHEA sulfate, androstenediol, androstenediol sulfate, and androstenedione can also synthesize testosterone, because the enzyme that converts androstenedione into testosterone (AKR1C3) is also active in this adrenal zone (Nakamura et al. 2009). In addition, a substantial portion of testosterone in both sexes may arise from adrenal steroids (mainly DHEA) that are converted to testosterone in peripheral tissues. Another source of testosterone in pregnancy may be the testicles of the male fetus, but these are only active in the first trimester of pregnancy in terms of testosterone production. Although testosterone is a key male testicular hormone, it also affects many physiological functions in women, both in pregnancy and beyond (Labrie 2010, Labrie 2015, Labrie et al. 2003) and testosterone production in the fetal testes in the first trimester of pregnancy provides the hormonal control of fetal sexual development (Huhtaniemi 1994).

Overproduction of testosterone in women may indicate a number of pathologies, mainly related to adrenal and/or ovarian disorders. Hyperandrogenism is generally associated with predisposition to $\beta$-cell dysfunction in women (Diamond et al. 1998, Navarro et al. 2015). Testosterone increases GSIS in $\beta$-cells by binding to extranuclear androgen receptors that induce cAMP production and activate cAMP-dependent protein kinase A in a similar way to GLP-1 (Mauvais-Jarvis 2016)). In animal models, $5 \alpha$-DHT infusion in females leads to hyperinsulinemia and IR dependent on the AR via a cAMP- and mTOR- dependent pathway. In $\beta$-cells, $5 \alpha$-DHT induces increased mitochondrial respiration associated with increased oxygen consumption and subsequent increased oxidative damage to these cells (Navarro et al. 2018). A positive correlation was found between maternal and fetal testosterone levels in male neonates. Testosterone levels were higher in newborns in mothers with GDM+ (Morisset et al. 2013). Even in non-diabetic populations of pregnant women, both total and free testosterone levels are positively correlated with fasting C-peptide levels (Ackerman et al. 2013) and abnormal increases in androgen levels during pregnancy are associated with a high risk of developing GDM (Makieva et al. 2014). In a study involving patients with GDM+ and appropriate controls, a significant positive relationship of circulating testosterone to insulin response following oral glucose administration was observed, while a negative correlation between testosterone and IS was observed.

\section{Estradiol}

In postmenopausal women, all sex steroids, including estradiol, are produced intracellularly in peripheral tissues (Labrie 2015), while in men, estradiol is produced predominantly by peripheral conversion of testicular and adrenal androgens (testosterone and androstenedione) in adipose tissue that exhibits relatively high CYP19A1 activity (Belanger et al. 2002, Labrie 2010, Rubinow 2018). In the luteal phase, most estrogens are produced in the ovaries, and in pregnancy, estradiol is almost exclusively a product of the placenta as mentioned above (Hill et al. 2010a, Simpson 2003).

Estrogens in postmenopausal women and men are not drivers of estrogen action, they are more reactive than proactive, since in these cases the circulating estrogen originates from non-gonadal sites, acts locally and only then enters circulation. Therefore, the circulating estrogens levels here rather reflect their effects, but are not their controlling element (Berkane et al. 2017, Simpson 2003).

A completely different situation occurs in women in the luteal phase and even more so in pregnancy, where the sex hormone estradiol affects and/or provides a range of physiological functions and is involved in the pathophysiology of various disorders (Berkane et al. 2017, Hill et al. 2010a, Simpson 2003).

During pregnancy, insulin levels in plasma increase in tandem with estradiol increase (Ropero et al. 2008). Estrogens participate in both rapid non-genomic and slow, genomic regulation of insulin secretion. As for the non-genomic effects of estrogens, estradiol binds to 
estrogen receptors (ER) such as type $\alpha$ ER $(E R \alpha)$ and type $\beta$ ER (ER $\beta)$, modulating the transcription of target pancreatic genes (Morimoto et al. 2011). While ER $\alpha$ are involved in the production of insulin and maintenance of nutritional homeostasis, ER $\beta$ is involved in increasing the GSIS. G protein-coupled ER (GPER), which is located in an extranuclear position, is involved in the regulation of GSIS and in the survival of $\beta$-cells (Mauvais-Jarvis 2016). ER $\alpha$, which is expressed in pancreatic islets instigates activation of MAPKs (mitogen-activated protein kinases) (Sutter-Dub 2002) and also induces expression of glucose transporter 4 (GLUT4). The GLUT4 plays a key role in glucose homeostasis and is a limiting step in the uptake of glucose in skeletal muscles that is induced by insulin.

In addition to the slow genomic effect, estradiol also produces rapid non-genomic effects through activation of the membrane-initiated signal pathways. The endocrine pancreatic cell response includes estradiol binding to membrane receptors followed by a change in membrane potential, an increase in $\mathrm{Ca}^{2+}$ influx into the cell, and the activation of protein kinase, cyclic guanosine monophosphate (cGMP) dependent kinase, and mitogenactivated protein kinase (Mauvais-Jarvis 2016, Morimoto et al. 2011, Sutter-Dub 2002). In physiological concentrations, estradiol increases cGMP levels in $\beta$-cells as well as the activity of the protein kinase $G$ (PKG), which subsequently reduces $\mathrm{K}_{\mathrm{ATP}}$ activity through the rapid and reversible closure $\mathrm{K}_{\mathrm{ATP}}$ channels. In synergy with increased glucose levels, it also depolarizes the cell membrane, triggering electrical activity and influx $\mathrm{Ca}^{2+}$ into the cell via activation of voltage-gated $\mathrm{Ca}^{2+}$ channels, leading to $\mathrm{Ca}^{2+}$ oscillations and consequently to pulsatile insulin secretion and the activation of $\mathrm{Ca}^{2+}$-dependent transcription. In glucagon synthesizing $\alpha$-cells, estradiol abolishes $\mathrm{Ca}^{2+}$ oscillations generated by low glucose levels, reducing glucagon secretion (Nadal et al. 1998, Ropero et al. 2002) (see also reviews (Morimoto et al. 2011, Ripoll et al. 2008, Ropero et al. 2008)). Moreover, estradiol inhibits the permeability of voltage dependent potassium channels (KQT-like subfamily member1, KCNQ1), which also activate $\beta$-cells (Moller and Netzer 2006). At the same time, estradiol levels in the maternal circulation exceed by approximately two orders of magnitude their value in the luteal phase of the menstrual cycle (Hill et al. 2011). The L-type $\mathrm{Ca}^{2+}$ channels may also participate in the regulation of peripheral IS (Xu et al. 2004). In addition to insulin secretion, estrogens stimulate energy consumption and food intake by affecting the CNS, increasing glucose uptake in muscles and adipocytes, and decreasing liver gluconeogenesis.
(Mauvais-Jarvis 2011).

Concerning the associations between estrogens and GDM development, reduction of GLUT4 expression contributes to the reduction of IS (Morimoto et al. 2011). In addition, ER $\alpha$ are involved in modulation of hepatic IS because ER $\alpha$ KO mice show severe hepatic IR and undesirable changes in skeletal glucose uptake. Absence of ERs is associated with IR and glucose intolerance and leads to adipocyte hyperplasia and hypertrophy in WAT but not in brown adipose tissue (Ropero et al. 2008). Both ER KO and aromatase KO mice are obese and insulin resistant see review (Ropero et al. 2008). Longterm exposure to estradiol physiological levels, on the other hand, results in increased expression of the insulin gene and increased release of insulin with Era (AlonsoMagdalena et al. 2008). ER $\alpha$ also operate at the central level as their disruption in in the ventromedial nucleus of the hypothalamus of female mice leads to increased visceral adiposity, hyperphagia, hyperglycemia, and impaired energy exposure (Ropero et al. 2008). The lack of estradiol in female rats results in reduced expression of the gene for $\mathrm{K}_{\mathrm{ATP}}$ resulting in a decreased insulin secretion, which may be restored by estradiol replacement (Choi et al. 2005, Morimoto et al. 2001).

\section{Neuroactive steroids}

Neuroactive steroids affecting ion channel permeability include some of the steroids discussed above, such as sulfates of pregnenolone and DHEA, or estradiol. However, neuroactive steroids also include a group of $5 \alpha / \beta$-reduced progesterone metabolites, which are formed by conversion of progesterone mainly in the placenta and liver of both the fetus and the mother. High levels of these metabolites reflect extreme levels of progesterone in pregnancy, achieving pharmacologically effective concentrations at a number of receptors, in the direction of neuro-inhibition as well as neuro-excitation, depending on the $3 \alpha$ - or $3 \beta$-position of the hydroxy-group and the sulfated or non-sulfated form of the steroid (Hill et al. 2010a, Hill et al. 2011, Hill et al. 2014).

The $5 \alpha / \beta$ reduced progesterone metabolites could also be involved in the regulation of glucose homeostasis in pregnancy by the following mechanisms. It is known that estradiol produces a rapid opposite effect on the $\mathrm{Ca}^{2+}$ influx into the pancreatic $\beta$ - and $\alpha$-cells. Unlike $\beta$-cells, estradiol inhibits the $\mathrm{Ca}^{2+}$ influx oscillations and subsequently glucagon secretion in pancreatic $\alpha$-cells (Nadal et al. 2004). However, the $\beta$-cells produce significant amounts of aminobutyric acid (GABA), resulting in GABA receptor type A activation 
$\left(\mathrm{GABA}_{\mathrm{A}} \mathrm{R}\right)$ and subsequent inhibition of glucagon secretion in pancreatic $\alpha$-cells (Jin et al. 2013). Meanwhile, insulin negatively modulates $\mathrm{GABA}_{\mathrm{A}} \mathrm{R}$ via an ERK-dependent negative feedback loop mechanism (Bansal et al. 2011). The GABA increases insulin secretion at low concentrations but inhibits it at higher concentrations (Dong et al. 2006). GABAergic progesterone metabolites such as allopregnanolone and pregnanolone (at concentrations common in the circulation of the fetus and mother) increase the permeability of $\mathrm{GABA}_{\mathrm{A}} \mathrm{R}$ receptors for $\mathrm{Cl}^{-}$ions (Fodor et al. 2005, Hill et al. 2010a, Hill et al. 2010c, Hill et al. 2011, Hill et al. 2014, Park-Chung et al. 1999). Conversely, sulfated $\Delta^{5}$ steroids (at physiological concentrations) are their antagonists (Gartside et al. 2010, Mtchedlishvili and Kapur 2003, Park-Chung et al. 1999).

It is therefore likely that these progesterone metabolites could also influence glucose homeostasis in pregnancy and therefore the development of GDM. The same could be true in another case. It has been described that low glucose levels induce increased permeability of AMPA/kainate receptors for $\mathrm{Ca}^{2+}$ ions and opening of voltage dependent $\mathrm{Ca}^{2+}$ channels, stimulating glucagon secretion (Cabrera et al. 2008). While PregS and allopregnanolone inhibit the AMPA/kainate receptors (Sun et al. 2005, Yaghoubi et al. 1998) and hence glucagon secretion, estradiol acts as their antagonist $(\mathrm{Gu}$ and Moss 1996). In this context, it should be noted that levels of both pregnenolone sulfate and allopregnanolone are substantially elevated during pregnancy (Hill et al. 2010a, Hill et al. 2010c, Hill et al. 2011, Hill et al. 2014). To conclude, the influence of neuroactive steroids on the secretion of endocrine pancreatic hormones is undoubtedly worth considering in the context of GDM pathophysiology.

\section{GDM, cortisol, and inflammation}

Cortisol is commonly known as the most important human glucocorticoid produced in the zona fasciculata of the adult adrenal cortex and its production is controlled by the hypothalamic-pituitary-adrenal (HPA) axis. Cortisol is also well known to suppress the immune response and affect glucose homeostasis. The fetus produces cortisol in an analogous zone known as transition zone of the fetal adrenal, but its production largely depends on placental $\mathrm{CRH}$, with which cortisol can generate a positive feedback loop as was describe above (Hill et al. 2014).

Besides pregnancy related tissues such as fetal adrenal and placenta, the expression of mRNA for $\mathrm{CRH}$ and CRH-receptor type 1 (CRHR1) and of protein for CRHR1 was found in rat and human pancreatic islets and rat insulinoma cells. Furthermore, mRNA for HSD11B1 and HSD11B2 and protein for HSD11B1 were reported in in rat and human pancreatic islets and insulinoma cells (Schmid et al. 2011). Stimulation of CRHR1 and GHRH receptors suppresses HSD11B1 while simultaneously upregulating HSD11B2 in insulinoma cells. The effect is therefore a shift the balance away from active glucocorticoid towards its inactive form (Schmid et al. 2011).

Pregnancy is associated with persistent mild proinflammatory state and elevated glucose levels. Excessive CRH levels in the mother's blood stimulate the placental production of pro-inflammatory cytokines such as TNF $\alpha$, IL-1 $\beta$, IL-6, and IL-8. While CRH binding to CRH receptors type 1 (CRH1) produces a pro-inflammatory effect, the CRH binding to $\mathrm{CRH}$ receptors type 2 (CRH2) does the opposite. At the same time, however, cortisol, whose levels are stimulated by CRH, has anti-inflammatory effects that are associated with an increase in IR beyond the cytokine signaling pathways. This means that cortisol can simultaneously mitigate the pro-inflammatory effects of CRH (Gangestad et al. 2012). In terms of the role of cortisol in pathophysiology, it is important that increases in stress hormone levels and stress adaptation disorders may be associated with the pathogenesis of GDM (Feng et al. 2020).

\section{Concluding remarks and future prospects}

As GDM is both a frequent and serious pregnancy complication, steroid levels in pregnancy are extremely elevated and their role in pregnancy is crucial, this review focuses on the role of steroids and some steroid associated substances in the pathophysiology of GDM. Of these substances, the SHBG in particular plays an important role. Low levels of this binding protein synthesized in the maternal liver are associated with IR and hyperinsulinemia, while also well predicting a predisposition to GDM.

Other important agents involved in the pathophysiology of GDM are placental peptide hormones such as kisspeptin and $\mathrm{CRH}$, which play an important role beyond pregnancy, but are synthesized here in considerably smaller amounts in the hypothalamus. These hormones have their receptors in tissues that affect both the course and termination of pregnancy, such as the fetal adrenal gland, as well as in tissues associated with GDM pathophysiology, such as pancreas. These substances therefore substantially influence the synthesis of pregnancy steroids and may also be involved in the 
pathophysiology of GDM.

Steroids themselves, whose biosynthesis in pregnancy is mainly provided by the fetal adrenal glands, placenta, maternal adrenal glands, and both maternal and fetal livers, are also synthesized in limited amounts directly in the pancreas and may influence the development of GDM. These substances involve sulfates of $\Delta^{5}$ steroids primarily acting by modulating different ion channels and influencing the development of GDM in different directions, predominantly diabetogenic progesterone but predominantly anti-diabetic estradiol, acting both in genomic and non-genomic way, androgens associated (in a similar way to progesterone) with IR and hyperinsulinemia, neuroactive steroids affecting the pituitary functioning and cortisol, the production of which is stimulated by CRH but which also suppresses its pro-inflammatory effects.

However, due to the complex effect of a number of steroids, steroidomic studies assessing their predominant or resulting effect are desirable in the future, similarly to studies assessing their predictive values for estimating predisposition to GDM.

\section{Conflict of Interest}

There is no conflict of interest.

\section{Acknowledgements}

Grants NV17-30528A Prediction of gestational diabetes, on the basis of steroid metabolism, NU20-04-00389 Role of neuroactive steroids in mechanism of action of clozapine, and NU20-01-00308 Longitudinal monitoring of glucose tolerance dynamics - risk and protective factors from the Czech Research Health Council, and MH CZ DRO (Institute of Endocrinology - EÚ, 00023761) Longterm conceptual development of the research organization based on the evaluation of its results supported this study.

\section{References}

BioGPS; 2011/11/13; Affymetrix: Santa Clara, CA, USA, 2016.

ACKERMAN CM, LOWE LP, DYER AR, HAYES MG, METZGER BE, LOWE WL, URBANEK M, and GROUP HSCR: Maternal testosterone levels are associated with C-peptide levels in the Mexican American subset of the Hyperglycemia and Adverse Pregnancy Outcome (HAPO) Study cohort. Horm Metab Res 45: 617-620, 2013. https://doi.org/10.1055/s-0033-1347262

ALONSO-MAGDALENA P, ROPERO AB, CARRERA MP, CEDERROTH CR, BAQUIE M, GAUTHIER BR, NEF S, STEFANI E, and NADAL A: Pancreatic insulin content regulation by the estrogen receptor ER alpha. PLoS One 3: e2069, 2008. https://doi.org/10.1371/journal.pone.0002069

ANDREOZZI F, MANNINO GC, MANCUSO E, SPIGA R, PERTICONE F, SESTI G: Plasma kisspeptin levels are associated with insulin secretion in nondiabetic individuals. PLoS One 12: e0179834, 2017. https://doi.org/10.1371/journal.pone.0179834

BANSAL P, WANG S, LIU S, XIANG YY, LU WY, WANG Q: GABA coordinates with insulin in regulating secretory function in pancreatic INS-1 beta-cells. PLoS One 6: e26225, 2011. https://doi.org/10.1371/journal.pone.0026225

BARTHA JL, COMINO-DELGADO R, ROMERO-CARMONA R, GOMEZ-JAEN MC: Sex hormone-binding globulin in gestational diabetes. Acta Obstet Gynecol Scand 79: 839-845, 2000. https://doi.org/10.3109/00016340009169212

BELANGER C, LUU-THE V, DUPONT P, TCHERNOF A: Adipose tissue intracrinology: potential importance of local androgen/estrogen metabolism in the regulation of adiposity. Horm Metab Res 34: 737-745, 2002. https://doi.org/10.1055/s-2002-38265

BERKANE N, LIERE P, OUDINET JP, HERTIG A, LEFEVRE G, PLUCHINO N, SCHUMACHER M, CHABBERT-BUFFET N: From pregnancy to preeclampsia: a key role for estrogens. Endocr Rev 38: 123-144, 2017. https://doi.org/10.1210/er.2016-1065

BERNARD-KARGAR C, KTORZA A: Endocrine pancreas plasticity under physiological and pathological conditions. Diabetes 50 Suppl 1: S30-S35, 2001. https://doi.org/10.2337/diabetes.50.2007.S30

BOWE JE, HILL TG, HUNT KF, SMITH LI, SIMPSON SJ, AMIEL SA, and JONES PM: A role for placental kisspeptin in beta cell adaptation to pregnancy. JCI Insight 4: 2019. https://doi.org/10.1172/jci.insight.124540

BRANISTEANU DD, and MATHIEU C: Progesterone in gestational diabetes mellitus: guilty or not guilty? Trends Endocrinol Metab 14: 54-6, 2003. https://doi.org/10.1016/S1043-2760(03)00003-1 
BUCHANAN TA, and XIANG AH: Gestational diabetes mellitus. J Clin Invest 115: 485-491, 2005. https://doi.org/10.1172/JCI200524531

BURNSTOCK G: Purinergic signalling in endocrine organs. Purinergic Signal 10: 189-231, 2014. https://doi.org/10.1007/s11302-013-9396-X

CABRERA O, JACQUES-SILVA MC, SPEIER S, YANG SN, KOHLER M, FACHADO A, VIEIRA E, ZIERATH JR, KIBBEY R, BERMAN DM, KENYON NS, RICORDI C, CAICEDO A, and BERGGREN PO: Glutamate is a positive autocrine signal for glucagon release. Cell Metab 7: 545-554, 2008. https://doi.org/10.1016/j.cmet.2008.03.004

CAMPBELL EA, LINTON EA, WOLFE CD, SCRAGGS PR, JONES MT, and LOWRY PJ: Plasma corticotropinreleasing hormone concentrations during pregnancy and parturition. J Clin Endocrinol Metab 64: 1054-1059, 1987. https://doi.org/10.1210/jcem-64-5-1054

CATALANO PM: Trying to understand gestational diabetes. Diabet Med 31: 273-281, 2014. https://doi.org/10.1111/dme.12381

CATALANO PM, HUSTON L, AMINI SB, and KALHAN SC: Longitudinal changes in glucose metabolism during pregnancy in obese women with normal glucose tolerance and gestational diabetes mellitus. Am J Obstet Gynecol 180: 903-916, 1999. https://doi.org/10.1016/S0002-9378(99)70662-9

CHOI SB, JANG JS, PARK S: Estrogen and exercise may enhance beta-cell function and mass via insulin receptor substrate 2 induction in ovariectomized diabetic rats. Endocrinology 146: 4786-4794, 2005. https://doi.org/10.1210/en.2004-1653

DE ROO M, BOUE-GRABOT E, SCHLICHTER R: Selective potentiation of homomeric P2X2 ionotropic ATP receptors by a fast non-genomic action of progesterone. Neuropharmacology 58: 569-577, 2010. https://doi.org/10.1016/j.neuropharm.2009.12.002

DE ROO M, RODEAU JL, SCHLICHTER R: Dehydroepiandrosterone potentiates native ionotropic ATP receptors containing the P2X2 subunit in rat sensory neurones. J Physiol 552: 59-71, 2003. https://doi.org/10.1113/jphysiol.2003.046078

DIAMOND MP, GRAINGER D, DIAMOND MC, SHERWIN RS, DEFRONZO RA: Effects of methyltestosterone on insulin secretion and sensitivity in women. J Clin Endocrinol Metab 83: 4420-4425, 1998. https://doi.org/10.1210/jc.83.12.4420

DING EL, SONG Y, MANSON JE, HUNTER DJ, LEE CC, RIFAI N, BURING JE, GAZIANO JM, LIU S: Sex hormone-binding globulin and risk of type 2 diabetes in women and men. N Engl J Med 361: 1152-1163, 2009. https://doi.org/10.1056/NEJMoa0804381

DONG H, KUMAR M, ZHANG Y, GYULKHANDANYAN A, XIANG YY, YE B, PERRELLA J, HYDER A, ZHANG N, WHEELER M, LU WY, and WANG Q: Gamma-aminobutyric acid up- and downregulates insulin secretion from beta cells in concert with changes in glucose concentration. Diabetologia 49: 697-705, 2006. https://doi.org/10.1007/s00125-005-0123-1

DREWS A, MOHR F, RIZUN O, WAGNER TF, DEMBLA S, RUDOLPH S, LAMBERT S, KONRAD M, PHILIPP SE, BEHRENDT M, MARCHAIS-OBERWINKLER S, COVEY DF, and OBERWINKLER J: Structural requirements of steroidal agonists of transient receptor potential melastatin 3 (TRPM3) cation channels. Br J Pharmacol 171: 1019-1032, 2014. https://doi.org/10.1111/bph.12521

FAAL S, ABEDI P, JAHANFAR S, NDEKE JM, MOHAGHEGH Z, SHARIFIPOUR F, and ZAHEDIAN M: Sex hormone binding globulin for prediction of gestational diabetes mellitus in pre-conception and pregnancy: A systematic review. Diabetes Res Clin Pract 152: 39-52, 2019. https://doi.org/10.1016/j.diabres.2019.04.028

FENG Y, FENG Q, QU H, SONG X, HU J, XU X, ZHANG L, and YIN S: Stress adaptation is associated with insulin resistance in women with gestational diabetes mellitus. Nutr Diabetes 10: 4, 2020. https://doi.org/10.1038/s41387-020-0107-8

FODOR L, BIRO T, MAKSAY G: Nanomolar allopregnanolone potentiates rat cerebellar GABAA receptors. Neurosci Lett 383: 127-30, 2005. https://doi.org/10.1016/j.neulet.2005.03.064

GANGESTAD SW, CALDWELL HOOPER AE, EATON MA: On the function of placental corticotropin-releasing hormone: a role in maternal-fetal conflicts over blood glucose concentrations. Biol Rev Camb Philos Soc 87: 856-873, 2012. https://doi.org/10.1111/j.1469-185X.2012.00226.X 
GARTSIDE SE, GRIFFITH NC, KAURA V, INGRAM CD: The neurosteroid dehydroepiandrosterone (DHEA) and its metabolites alter 5-HT neuronal activity via modulation of GABAA receptors. J Psychopharmacol 24: 1717-1724, 2010. https://doi.org/10.1177/0269881109105836

GOLAND RS, JOZAK S, CONWELL I: Placental corticotropin-releasing hormone and the hypercortisolism of pregnancy. Am J Obstet Gynecol 171: 1287-1291, 1994. https://doi.org/10.1016/0002-9378(94)90149-X

GOLAND RS, WARDLAW SL, BLUM M, TROPPER PJ, and STARK RI: Biologically active corticotropin-releasing hormone in maternal and fetal plasma during pregnancy. Am J Obstet Gynecol 159: 884-890, 1988. https://doi.org/10.1016/S0002-9378(88)80162-5

GU Q, MOSS RL: 17 beta-Estradiol potentiates kainate-induced currents via activation of the cAMP cascade. J Neurosci 16: 3620-3629, 1996. https://doi.org/10.1523/JNEUROSCI.16-11-03620.1996

HEDDERSON MM, XU F, DARBINIAN JA, QUESENBERRY CP, SRIDHAR S, KIM C, GUNDERSON EP, and FERRARA A: Prepregnancy SHBG concentrations and risk for subsequently developing gestational diabetes mellitus. Diabetes Care 37: 1296-1303, 2014. https://doi.org/10.2337/dc13-1965

HERRMANN TS, SIEGA-RIZ AM, HOBEL CJ, AURORA C, DUNKEL-SCHETTER C: Prolonged periods without food intake during pregnancy increase risk for elevated maternal corticotropin-releasing hormone concentrations. Am J Obstet Gynecol 185: 403-412, 2001. https://doi.org/10.1067/mob.2001.115863

HILL M, LUKAC D, LAPCIK O, SULCOVA J, HAMPL R, POUZAR V, STARKA L: Age relationships and sex differences in serum levels of pregnenolone and 17-hydroxypregnenolone in healthy subjects. Clin Chem Lab Med 37: 439-47, 1999. https://doi.org/10.1515/CCLM.1999.072

HILL M, PARIZEK A, CIBULA D, KANCHEVA R, JIRASEK JE, JIRKOVSKA M, VELIKOVA M, KUBATOVA J, KLIMKOVA M, PASKOVA A, ZIZKA Z, KANCHEVA L, KAZIHNITKOVA H, ZAMRAZILOVA L, STARKA L: Steroid metabolome in fetal and maternal body fluids in human late pregnancy. J Steroid Biochem Mol Biol 122: 114-32, 2010a. https://doi.org/10.1016/i.jsbmb.2010.05.007

HILL M, PARIZEK A, JIRASEK JE, JIRKOVSKA M, VELIKOVA M, DUSKOVA M, KLIMKOVA M, PASKOVA A, ZIZKA Z, GERMANOVA A, KOUCKY M, KALOUSOVA M, STARKA L: Is maternal progesterone actually independent of the fetal steroids? Physiol Res 59: 211-224, $2010 \mathrm{~b}$. https://doi.org/10.33549/physiolres.931807

HILL M, PARIZEK A, KANCHEVA R, DUSKOVA M, VELIKOVA M, KRIZ L, KLIMKOVA M, PASKOVA A, ZIZKA Z, MATUCHA P, MELOUN M, STARKA L: Steroid metabolome in plasma from the umbilical artery, umbilical vein, maternal cubital vein and in amniotic fluid in normal and preterm labor. J Steroid Biochem Mol Biol 121: 594-610, 2010c. https://doi.org/10.1016/j.jsbmb.2009.10.012

HILL M, PARIZEK A, VELIKOVA M, KUBATOVA J, KANCHEVA R, DUSKOVA M, SIMUNKOVA K, KLIMKOVA M, PASKOVA A, ZIZKA Z, JIRASEK JE, JIRKOVSKA M, STARKA L: The distribution of placental oxidoreductase isoforms provides different milieus of steroids influencing pregnancy in the maternal and fetal compartment. Horm Mol Biol Clin Invest 4: 581-600, 2011. https://doi.org/10.1515/HMBCI.2010.077

HILL M, PASKOVA A, KANCEVA R, VELIKOVA M, KUBATOVA J, KANCHEVA L, ADAMCOVA K, MIKESOVA M, ZIZKA Z, KOUCKY M, SARAPATKOVA H, KACER V, MATUCHA P, MELOUN M, PARIZEK A: Steroid profiling in pregnancy: a focus on the human fetus. J Steroid Biochem Mol Biol 139: 201-22, 2014. https://doi.org/10.1016/j.jsbmb.2013.03.008

HU KL, ZHAO H, YU Y, LI R: Kisspeptin as a potential biomarker throughout pregnancy. Eur J Obstet Gynecol Reprod Biol 240: 261-266, 2019. https://doi.org/10.1016/j.ejogrb.2019.07.016

HUHTANIEMI I: Fetal testis--a very special endocrine organ. Eur J Endocrinol 130: 25-31, 1994. https://doi.org/10.1530/eje.0.1300025

JIN Y, KOROL SV, JIN Z, BARG S, BIRNIR B: In intact islets interstitial GABA activates GABA(A) receptors that generate tonic currents in alpha-cells. PLoS One 8: e67228, 2013. https://doi.org/10.1371/journal.pone.0067228

KANCHEVA R, HILL M, CIBULA D, VCELAKOVA H, KANCHEVA L, VRBIKOVA J, FAIT T, PARIZEK A, STARKA L: Relationships of circulating pregnanolone isomers and their polar conjugates to the status of sex, menstrual cycle, and pregnancy. J Endocrinol 195: 67-78, 2007. https://doi.org/10.1677/JOE-06-0192 
KATUGAMPOLA H, KING PJ, CHATTERJEE S, MESO M, DUNCAN AJ, ACHERMANN JC, GUASTI L, GHATAORE L, TAYLOR NF, ALLEN R, MARLENE S, AQUILINA J, ABBARA A, JAYSENA CN, DHILLO WS, DUNKEL L, SANKILAMPI U, STORR HL: Kisspeptin Is a Novel Regulator of Human Fetal Adrenocortical Development and Function: A Finding With Important Implications for the Human Fetoplacental Unit. J Clin Endocrinol Metab 102: 3349-3359, 2017. https://doi.org/10.1210/jc.2017-00763

KAUTZKY-WILLER A, PRAGER R, WALDHAUSL W, PACINI G, THOMASETH K, WAGNER OF, ULM M, STRELI C, LUDVIK B: Pronounced insulin resistance and inadequate beta-cell secretion characterize lean gestational diabetes during and after pregnancy. Diabetes Care 20: 1717-1723, 1997. https://doi.org/10.2337/diacare.20.11.1717

KAWAI M, KISHI K: Adaptation of pancreatic islet B-cells during the last third of pregnancy: regulation of B-cell function and proliferation by lactogenic hormones in rats. Eur J Endocrinol 141: 419-425, 1999. https://doi.org/10.1530/eje.0.1410419

KENNA LA, OLSEN JA, SPELIOS MG, RADIN MS, AKIRAV EM: beta-Cell death is decreased in women with gestational diabetes mellitus. Diabetol Metab Syndr 8: 60, 2016. https://doi.org/10.1186/s13098-016-0175-Z

KOPP HP, FESTA A, KRUGLUGER W, SCHERNTHANER G: Low levels of Sex-Hormone-Binding Globulin predict insulin requirement in patients with gestational diabetes mellitus. Exp Clin Endocrinol Diabetes 109: 365-9, 2001. https://doi.org/10.1055/s-2001-17408

KRAMER CK, SWAMINATHAN B, HANLEY AJ, CONNELLY PW, SERMER M, ZINMAN B, RETNAKARAN $\mathrm{R}$ : Each degree of glucose intolerance in pregnancy predicts distinct trajectories of beta-cell function, insulin sensitivity, and glycemia in the first 3 years postpartum. Diabetes Care 37: 3262-3269, 2014. https://doi.org/10.2337/dc14-1529

KUDO K, TACHIKAWA E, KASHIMOTO T: Inhibition by pregnenolone sulfate of nicotinic acetylcholine response in adrenal chromaffin cells. Eur J Pharmacol 456: 19-27, 2002. https://doi.org/10.1016/S0014-2999(02)02623-7

KWAK SH, KIM SH, CHO YM, GO MJ, CHO YS, CHOI SH, MOON MK, JUNG HS, SHIN HD, KANG HM, CHO NH, LEE IK, KIM SY, HAN BG, JANG HC, PARK KS: A genome-wide association study of gestational diabetes mellitus in Korean women. Diabetes 61: 531-541, 2012. https://doi.org/10.2337/db11-1034

LABRIE F: DHEA, important source of sex steroids in men and even more in women. Prog Brain Res 182: 97-148, 2010. https://doi.org/10.1016/S0079-6123(10)82004-7

LABRIE F: All sex steroids are made intracellularly in peripheral tissues by the mechanisms of intracrinology after menopause. J Steroid Biochem Mol Biol 145: 133-138, 2015. https://doi.org/10.1016/j.jsbmb.2014.06.001

LABRIE F, LUU-THE V, LABRIE C, BELANGER A, SIMARD J, LIN SX, PELLETIER G: Endocrine and intracrine sources of androgens in women: inhibition of breast cancer and other roles of androgens and their precursor dehydroepiandrosterone. Endocr Rev 24: 152-182, 2003. https://doi.org/10.1210/er.2001-0031

LAMBERT S, DREWS A, RIZUN O, WAGNER TF, LIS A, MANNEBACH S, PLANT S, PORTZ M, MEISSNER M, PHILIPP SE, OBERWINKLER J: Transient receptor potential melastatin 1 (TRPM1) is an ion-conducting plasma membrane channel inhibited by zinc ions. $J$ Biol Chem 286: 12221-12233, 2011. https://doi.org/10.1074/jbc.M110.202945

LESCH A, RUBIL S, THIEL G: Activation and inhibition of transient receptor potential TRPM3-induced gene transcription. Br J Pharmacol 171: 2645-58, 2014. https://doi.org/10.1111/bph.12524

LIU D, REN M, BING X, STOTTS C, DEORAH S, LOVE-HOMAN L, DILLON JS: Dehydroepiandrosterone inhibits intracellular calcium release in beta-cells by a plasma membrane-dependent mechanism. Steroids 71: 691-699, 2006a. https://doi.org/10.1016/j.steroids.2006.04.001

LIU HK, GREEN BD, MCCLENAGHAN NH, MCCLUSKEY JT, FLATT PR: Deleterious effects of supplementation with dehydroepiandrosterone sulphate or dexamethasone on rat insulin-secreting cells under in vitro culture condition. Biosci Rep 26: 31-38, 2006b. https://doi.org/10.1007/s10540-006-9001-4

MACK LR, TOMICH PG: Gestational diabetes: diagnosis, classification, and clinical care. Obstet Gynecol Clin North Am 44: 207-217, 2017. https://doi.org/10.1016/j.ogc.2017.02.002

MAJEED Y, AGARWAL AK, NAYLOR J, SEYMOUR VA, JIANG S, MURAKI K, FISHWICK CW, BEECH DJ: Cis-isomerism and other chemical requirements of steroidal agonists and partial agonists acting at TRPM3 channels. Br J Pharmacol 161: 430-441, 2010. https://doi.org/10.1111/j.1476-5381.2010.00892.x 
MAJEED Y, TUMOVA S, GREEN BL, SEYMOUR VA, WOODS DM, AGARWAL AK, NAYLOR J, JIANG S, PICTON HM, PORTER KE, O'REGAN DJ, MURAKI K, FISHWICK CW, BEECH DJ: Pregnenolone sulphate-independent inhibition of TRPM3 channels by progesterone. Cell Calcium 51: 1-11, 2012. https://doi.org/10.1016/j.ceca.2011.09.005

MAKIEVA S, SAUNDERS PT, NORMAN JE: Androgens in pregnancy: roles in parturition. Hum Reprod Update 20: 542-559, 2014. https://doi.org/10.1093/humupd/dmu008

MAUVAIS-JARVIS F: Estrogen and androgen receptors: regulators of fuel homeostasis and emerging targets for diabetes and obesity. Trends Endocrinol Metab 22: 24-33, 2011. https://doi.org/10.1016/j.tem.2010.10.002

MAUVAIS-JARVIS F: Role of Sex Steroids in beta Cell Function, Growth, and Survival. Trends Endocrinol Metab 27: 844-855, 2016. https://doi.org/10.1016/j.tem.2016.08.008

MCELDUFF A, HITCHMAN R, MCELDUFF P: Is sex hormone-binding globulin associated with glucose tolerance? Diabet Med 23: 306-312, 2006. https://doi.org/10.1111/j.1464-5491.2005.01780.x

MCLEAN M, BISITS A, DAVIES J, WOODS R, LOWRY P, SMITH R: A placental clock controlling the length of human pregnancy. Nat Med 1: 460-463, 1995. https://doi.org/10.1038/nm0595-460

MEDINA MC, SOUZA LC, CAPERUTO LC, ANHE GF, AMANSO AM, TEIXEIRA VP, BORDIN S, CARPINELLI AR, BRITTO LR, BARBIERI RL, BORELLA MI, CARVALHO CR: Dehydroepiandrosterone increases beta-cell mass and improves the glucose-induced insulin secretion by pancreatic islets from aged rats. FEBS Lett 580: 285-290, 2006. https://doi.org/10.1016/j.febslet.2005.12.014

MIRGHANI DIRAR A, DOUPIS J: Gestational diabetes from A to Z. World J Diabetes 8: 489-511, 2017. https://doi.org/10.4239/wjd.v8.i12.489

MITAMURA K, NAGAOKA Y, SHIMADA K, HONMA S, NAMIKI M, KOH E, MIZOKAMI A: Simultaneous determination of androstenediol 3-sulfate and dehydroepiandrosterone sulfate in human serum using isotope diluted liquid chromatography-electrospray ionization-mass spectrometry. J Chromatogr B Analyt Technol Biomed Life Sci 796: 121-130, 2003. https://doi.org/10.1016/j.jchromb.2003.08.011

MOLLER C, NETZER R: Effects of estradiol on cardiac ion channel currents. Eur J Pharmacol 532: 44-49, 2006. https://doi.org/10.1016/j.ejphar.2006.01.006

MORALES A, CUELLAR A, RAMIREZ J, VILCHIS F, DIAZ-SANCHEZ V: Synthesis of steroids in pancreas: evidence of cytochrome P-450scc activity. Pancreas 19: 39-44, 1999. https://doi.org/10.1097/00006676$\underline{199907000-00006}$

MORIMOTO S, CERBON MA, ALVAREZ-ALVAREZ A, ROMERO-NAVARRO G, DIAZ-SANCHEZ V: Insulin gene expression pattern in rat pancreas during the estrous cycle. Life Sci 68: 2979-2985, 2001. https://doi.org/10.1016/S0024-3205(01)01100-6

MORIMOTO S, JIMENEZ-TREJO F, CERBON M: Sex steroids effects in normal endocrine pancreatic function and diabetes. Curr Top Med Chem 11: 1728-35, 2011. https://doi.org/10.2174/156802611796117540

MORISSET AS, DUBE MC, DROLET R, PELLETIER M, LABRIE F, LUU-THE V, TREMBLAY Y, ROBITAILLE J, JOHN WEISNAGEL S, TCHERNOF A: Androgens in the maternal and fetal circulation: association with insulin resistance. J Matern Fetal Neonatal Med 26: 513-519, 2013. https://doi.org/10.3109/14767058.2012.735725

MOYCE BL, DOLINSKY VW: Maternal beta-Cell Adaptations in Pregnancy and Placental Signalling: Implications for Gestational Diabetes. Int J Mol Sci 19: 2018. https://doi.org/10.3390/ijms19113467

MTCHEDLISHVILI Z, KAPUR J: A presynaptic action of the neurosteroid pregnenolone sulfate on GABAergic synaptic transmission. Mol Pharmacol 64: 857-864, 2003. https://doi.org/10.1124/mol.64.4.857

NADAL A, ROPERO AB, FUENTES E, SORIA B, RIPOLL C: Estrogen and xenoestrogen actions on endocrine pancreas: from ion channel modulation to activation of nuclear function. Steroids 69: 531-536, 2004. https://doi.org/10.1016/j.steroids.2004.05.010

NADAL A, ROVIRA JM, LARIBI O, LEON-QUINTO T, ANDREU E, RIPOLL C, SORIA B: Rapid insulinotropic effect of 17beta-estradiol via a plasma membrane receptor. FASEB J 12: 1341-1348, 1998. https://doi.org/10.1096/fasebj.12.13.1341

NAKAMURA Y, HORNSBY PJ, CASSON P, MORIMOTO R, SATOH F, XING Y, KENNEDY MR, SASANO H, RAINEY WE: Type 5 17beta-hydroxysteroid dehydrogenase (AKR1C3) contributes to testosterone production in the adrenal reticularis. J Clin Endocrinol Metab 94: 2192-8, 2009. https://doi.org/10.1210/jc.2008-2374 
NAVARRO G, ALLARD C, MORFORD JJ, XU W, LIU S, MOLINAS AJ, BUTCHER SM, FINE NH, BLANDINOROSANO M, SURE VN, YU S, ZHANG R, MUNZBERG H, JACOBSON DA, KATAKAM PV, HODSON DJ, BERNAL-MIZRACHI E, ZSOMBOK A, MAUVAIS-JARVIS F: Androgen excess in pancreatic beta cells and neurons predisposes female mice to type 2 diabetes. JCI Insight 3: 2018. https://doi.org/10.1172/jci.insight. 98607

NAVARRO G, ALLARD C, XU W, and MAUVAIS-JARVIS F: The role of androgens in metabolism, obesity, and diabetes in males and females. Obesity (Silver Spring) 23: 713-9, 2015. https://doi.org/10.1002/oby.21033

NAYLOR J, LI J, MILLIGAN CJ, ZENG F, SUKUMAR P, HOU B, SEDO A, YULDASHEVA N, MAJEED Y, BERI D, JIANG S, SEYMOUR VA, MCKEOWN L, KUMAR B, HARTENECK C, O'REGAN D, WHEATCROFT SB, KEARNEY MT, JONES C, PORTER KE, BEECH DJ: Pregnenolone sulphate- and cholesterol-regulated TRPM3 channels coupled to vascular smooth muscle secretion and contraction. Circ Res 106: 1507-1515, 2010. https://doi.org/10.1161/CIRCRESAHA.110.219329

NIELSEN JH: Direct effect of gonadal and contraceptive steroids on insulin release from mouse pancreatic islets in organ culture. Acta Endocrinol (Copenh) 105: 245-250, 1984. https://doi.org/10.1530/acta.0.1050245

PARADISO K, SABEY K, EVERS AS, ZORUMSKI CF, COVEY DF, STEINBACH JH: Steroid inhibition of rat neuronal nicotinic alpha4beta2 receptors expressed in HEK 293 cells. Mol Pharmacol 58: 341-351, 2000. https://doi.org/10.1124/mol.58.2.341

PARK-CHUNG M, MALAYEV A, PURDY RH, GIBBS TT, FARB DH: Sulfated and unsulfated steroids modulate gamma-aminobutyric acidA receptor function through distinct sites. Brain Res 830: 72-87, 1999. https://doi.org/10.1016/S0006-8993(99)01381-5

PICARD F, WANATABE M, SCHOONJANS K, LYDON J, O'MALLEY BW, AUWERX J: Progesterone receptor knockout mice have an improved glucose homeostasis secondary to beta -cell proliferation. Proc Natl Acad Sci U S A 99: 15644-15648, 2002. https://doi.org/10.1073/pnas.202612199

PLOWS JF, STANLEY JL, BAKER PN, REYNOLDS CM, VICKERS MH: The Pathophysiology of Gestational Diabetes Mellitus. Int J Mol Sci 19: 3342, 2018. https://doi.org/10.3390/ijms19113342

REBARBER A, ISTWAN NB, RUSSO-STIEGLITZ K, CLEARY-GOLDMAN J, RHEA DJ, STANZIANO GJ, SALTZMAN DH: Increased incidence of gestational diabetes in women receiving prophylactic 17alpha-hydroxyprogesterone caproate for prevention of recurrent preterm delivery. Diabetes Care 30: 2277-2280, 2007. https://doi.org/10.2337/dc07-0564

REGE J, KARASHIMA S, LERARIO AM, SMITH JM, AUCHUS RJ, KASA-VUBU JZ, SASANO H, NAKAMURA Y, WHITE PC, RAINEY WE: Age-dependent increases in adrenal cytochrome b5 and serum 5-androstenediol-3-sulfate. J Clin Endocrinol Metab jc20162864, 2016. https://doi.org/10.1210/jc.2016-2864

RIPOLL C, ROPERO AB, ALONSO-MAGDALENA P, QUESADA I, FUENTES E, and NADAL A: Rapid regulation of pancreatic alpha- and beta- cell signalling systems by estrogens. Infect Disord Drug Targets 8: 61-64, 2008. https://doi.org/10.2174/187152608784139668

ROBLES-DIAZ G, DUARTE-ROJO A: Pancreas: a sex steroid-dependent tissue. Isr Med Assoc J 3: 364-368, 2001.

ROPERO AB, ALONSO-MAGDALENA P, QUESADA I, and NADAL A: The role of estrogen receptors in the control of energy and glucose homeostasis. Steroids 73: 874-879, 2008. https://doi.org/10.1016/j.steroids.2007.12.018

ROPERO AB, SORIA B, NADAL A: A nonclassical estrogen membrane receptor triggers rapid differential actions in the endocrine pancreas. Mol Endocrinol 16: 497-505, 2002. https://doi.org/10.1210/mend.16.3.0794

RUBINOW KB: An intracrine view of sex steroids, immunity, and metabolic regulation. Mol Metab 15: 92-103, 2018. https://doi.org/10.1016/j.molmet.2018.03.001

SAISHO Y, MIYAKOSHI K, TANAKA M, SHIMADA A, IKENOUE S, KADOHIRA I, YOSHIMURA Y, ITOH H: Beta cell dysfunction and its clinical significance in gestational diabetes. Endocr J 57: 973-980, 2010. https://doi.org/10.1507/endocrj.K10E-231

SANDMAN CA, GLYNN L, SCHETTER CD, WADHWA P, GARITE T, CHICZ-DEMET A, HOBEL C: Elevated maternal cortisol early in pregnancy predicts third trimester levels of placental corticotropin releasing hormone (CRH): priming the placental clock. Peptides 27: 1457-1463, 2006. https://doi.org/10.1016/j.peptides.2005.10.002 
SASAKI A, SHINKAWA O, MARGIORIS AN, LIOTTA AS, SATO S, MURAKAMI O, GO M, SHIMIZU Y, HANEW K, YOSHINAGA K: Immunoreactive corticotropin-releasing hormone in human plasma during pregnancy, labor, and delivery. J Clin Endocrinol Metab 64: 224-229, 1987. https://doi.org/10.1210/jcem-64-2$\underline{224}$

SHAO J, QIAO L, FRIEDMAN JE: Prolactin, progesterone, and dexamethasone coordinately and adversely regulate glucokinase and cAMP/PDE cascades in MIN6 beta-cells. Am J Physiol Endocrinol Metab 286: E304-10, 2004. https://doi.org/10.1152/ajpendo.00210.2003

SCHMID J, LUDWIG B, SCHALLY AV, STEFFEN A, ZIEGLER CG, BLOCK NL, KOUTMANI Y, BRENDEL MD, KARALIS KP, SIMEONOVIC CJ, LICINIO J, EHRHART-BORNSTEIN M, BORNSTEIN SR: Modulation of pancreatic islets-stress axis by hypothalamic releasing hormones and 11beta-hydroxysteroid dehydrogenase. Proc Natl Acad Sci U S A 108: 13722-7, 2011. https://doi.org/10.1073/pnas.1110965108

SIMPSON ER: Sources of estrogen and their importance. J Steroid Biochem Mol Biol 86: 225-30, 2003. https://doi.org/10.1016/S0960-0760(03)00360-1

SIMPSON S, SMITH L, BOWE J: Placental peptides regulating islet adaptation to pregnancy: clinical potential in gestational diabetes mellitus. Curr Opin Pharmacol 43: 59-65, 2018. https://doi.org/10.1016/j.coph.2018.08.004

SMITH R, NICHOLSON RC: Corticotrophin releasing hormone and the timing of birth. Front Biosci 12: 912-918, 2007. https://doi.org/10.2741/2113

SMITH SR, DE JONGE L, PELLYMOUNTER M, NGUYEN T, HARRIS R, YORK D, REDMANN S, ROOD J, BRAY GA: Peripheral administration of human corticotropin-releasing hormone: a novel method to increase energy expenditure and fat oxidation in man. J Clin Endocrinol Metab 86: 1991-1998, 2001. https://doi.org/10.1210/jcem.86.5.7491

SOMM E, GUERARDEL A, MAOUCHE K, TOULOTTE A, VEYRAT-DUREBEX C, ROHNER-JEANRENAUD F, MASKOS U, HUPPI PS, SCHWITZGEBEL VM: Concomitant alpha7 and beta2 nicotinic AChR subunit deficiency leads to impaired energy homeostasis and increased physical activity in mice. Mol Genet Metab 112: 64-72, 2014. https://doi.org/10.1016/j.ymgme.2014.03.003

STERZL I, HAMPL R, HILL M, HRDA P, MATUCHA P: Immunomodulatory cytokines in human seminal plasma correlate with immunomodulatory steroids. Steroids 68: 725-731, 2003. https://doi.org/10.1016/S0039128X(03)00114-4

STERZL I, HAMPL R, STERZL J, VOTRUBA J, STARKA L: 7Beta-OH-DHEA counteracts dexamethasone induced suppression of primary immune response in murine spleenocytes. J Steroid Biochem Mol Biol 71: 133-137, 1999. https://doi.org/10.1016/S0960-0760(99)00134-X

STRAUB SG, SHARP GW, MEGLASSON MD, DE SOUZA CJ: Progesterone inhibits insulin secretion by a membrane delimited, non-genomic action. Biosci Rep 21: 653-666, 2001. https://doi.org/10.1023/A:1014773010350

SULCOVA J, HILL M, HAMPL R, STARKA L: Age and sex related differences in serum levels of unconjugated dehydroepiandrosterone and its sulphate in normal subjects. J Endocrinol 154: 57-62, 1997. https://doi.org/10.1677/joe.0.1540057

SUN JL, DONG YL, FU YM, ZHU YH, DONG Y, ZHENG P: Neurosteroid pregnenolone sulfate inhibits stimulusevoked EPSC via presynaptic inhibition of protein kinase $\mathrm{A}$ in rat prelimbic cortical neurons. $\begin{array}{llll}\text { Neuropharmacology } \quad 49: & 389-399, & 2005 . & 10.1016 / \text { j.neuropharm.2005.03.022 }\end{array}$ https://doi.org/10.1016/j.neuropharm.2005.03.022

SUTTER-DUB MT: Rapid non-genomic and genomic responses to progestogens, estrogens, and glucocorticoids in the endocrine pancreatic B cell, the adipocyte and other cell types. Steroids 67: 77-93, 2002. https://doi.org/10.1016/S0039-128X(01)00142-8

TAGAWA N, HIDAKA Y, TAKANO T, SHIMAOKA Y, KOBAYASHI Y, AMINO N: Serum concentrations of androstenediol and androstenediol sulfate, and their relation to cytokine production during and after normal pregnancy. Steroids 69: 675-680, 2004. https://doi.org/10.1016/j.steroids.2004.06.003

TAGAWA N, OHTA M, NAKAMURA N, NAKANO K, OBAYASHI H, KOBAYASHI Y: Serum concentrations of delta 5-3 beta-hydroxysteroids in type 2 diabetes mellitus. Biol Pharm Bull 25: 1634-1638, 2002. https://doi.org/10.1248/bpb.25.1634 
TAGAWA N, TAKANO T, FUKATA S, KUMA K, TADA H, IZUMI Y, KOBAYASHI Y, AMINO N: Serum concentration of androstenediol and androstenediol sulfate in patients with hyperthyroidism and hypothyroidism. Endocr J 48: 345-354, 2001. https://doi.org/10.1507/endocrj.48.345

TAGAWA N, TAMANAKA J, FUJINAMI A, KOBAYASHI Y, TAKANO T, FUKATA S, KUMA K, TADA H, AMINO N: Serum dehydroepiandrosterone, dehydroepiandrosterone sulfate, and pregnenolone sulfate concentrations in patients with hyperthyroidism and hypothyroidism. Clin Chem 46: 523-528, 2000. https://doi.org/10.1093/clinchem/46.4.523

TAWFEEK MA, ALFADHLI EM, ALAYOUBI AM, EL-BESHBISHY HA, HABIB FA: Sex hormone binding globulin as a valuable biochemical marker in predicting gestational diabetes mellitus. BMC Womens Health 17: 18, 2017. https://doi.org/10.1186/s12905-017-0373-3

VEJRAZKOVA D, VCELAK J, VANKOVA M, LUKASOVA P, BRADNOVA O, HALKOVA T, KANCHEVA R, BENDLOVA B: Steroids and insulin resistance in pregnancy. J Steroid Biochem Mol Biol 139: 122-9, 2014. https://doi.org/10.1016/j.jsbmb.2012.11.007

VERAS K, ALMEIDA FN, NACHBAR RT, DE JESUS DS, CAMPOREZ JP, CARPINELLI AR, GOEDECKE JH, DE OLIVEIRA CARVALHO CR: DHEA supplementation in ovariectomized rats reduces impaired glucosestimulated insulin secretion induced by a high-fat diet. FEBS Open Bio 4: 141-6, 2014. https://doi.org/10.1016/j.fob.2014.01.005

WANG L, YAN B, SHI X, SONG H, SU W, HUANG B, ZHANG Y, WANG S, LV F, LIN M, and LI X: Age at menarche and risk of gestational diabetes mellitus: a population-based study in Xiamen, China. BMC Pregnancy Childbirth 19: 138, 2019. https://doi.org/10.1186/s12884-019-2287-6

WEINHAUS AJ, BHAGROO NV, BRELJE TC, and SORENSON RL: Dexamethasone counteracts the effect of prolactin on islet function: implications for islet regulation in late pregnancy. Endocrinology 141: 1384-93, 2000. https://doi.org/10.1210/endo.141.4.7409

WILCOX G: Insulin and insulin resistance. Clin Biochem Rev 26: 19-39, 2005.

WOLFE CD, PATEL SP, LINTON EA, CAMPBELL EA, ANDERSON J, DORNHORST A, LOWRY PJ, JONES MT: Plasma corticotrophin-releasing factor (CRF) in abnormal pregnancy. Br J Obstet Gynaecol 95: 1003-6, 1988. https://doi.org/10.1111/j.1471-0528.1988.tb06504.x

XIANG AH, TAKAYANAGI M, BLACK MH, TRIGO E, LAWRENCE JM, WATANABE RM, BUCHANAN TA: Longitudinal changes in insulin sensitivity and beta cell function between women with and without a history of gestational diabetes mellitus. Diabetologia 56: 2753-60, 2013. https://doi.org/10.1007/s00125-013-3048-0

XU J, WANG P, LI Y, LI G, KACZMAREK LK, WU Y, KONI PA, FLAVELL RA, DESIR GV: The voltage-gated potassium channel Kv1.3 regulates peripheral insulin sensitivity. Proc Natl Acad Sci U S A 101: 3112-7, 2004. https://doi.org/10.1073/pnas.0308450100

YAGHOUBI N, MALAYEV A, RUSSEK SJ, GIBBS TT, FARB DH: Neurosteroid modulation of recombinant ionotropic glutamate receptors. Brain Res 803: 153-60, 1998. https://doi.org/10.1016/S0006-8993(98)00644-1

ZHANG B, JIN Z, SUN L, ZHENG Y, JIANG J, FENG C, and WANG Y: Expression and correlation of sex hormonebinding globulin and insulin signal transduction and glucose transporter proteins in gestational diabetes mellitus placental tissue. Diabetes Res Clin Pract 119: 106-17, 2016. https://doi.org/10.1016/j.diabres.2016.07.003

ZHANG X, SUN L, JIN Z: Effect of placental sex hormone-binding globulin single nucleotide polymorphism rs6259 on protein and function in gestational diabetes mellitus. Int J Mol Med 41: 2927-2934, 2018. https://doi.org/10.3892/ijmm.2018.3503 